\title{
The Reality of Married Female Students in the Bachelor's Degree at the World Islamic Science \& Education University W.I.S. E/ Jordan
}

\author{
Entisar Yousef Smadi ${ }^{1}$ \\ ${ }^{1}$ Associate Professor - Counseling and mental health department- World Islamic Science \& Education University \\ W.I.S. E -Amman-Jordan
}

Correspondence: Entisar Yousef Smadi, Associate Professor - Counseling and mental health department-International Islamic University of Science-Amman-Jordan. E-mail: entisarsmadi@yahoo.com

Received: February 7, 2020

Accepted: February 21, 2020

Online Published: February 26, 2020

doi:10.5539/mas.v14n3p56

URL: https://doi.org/10.5539/mas.v14n3p56

\begin{abstract}
The study aimed to identify the difficulties faced married female students, according to the variables: age, number of children, family income, educational level of the husband at the World Islamic Science \& Education University, during the second semester of the academic year 2018/2019, the sample of the study consisted of 64 married students, a scale was built that aims to measure the difficulties faced female students as a result of enrollment the university, the scale consists of twenty paragraphs. After conducting the study and result extraction, it appears that married females are enrolled in university studies based on mature decisions, these students were able to adapt well and this was demonstrated by the medium level of difficulties they suffer, and that the most level of difficulties faced female students has to do with the overlap and the increase in household burdens and university assignments, also, most married female students who suffer from difficulties are in the age group 31-40, with no trace of difficulties based on the family's income, the number of children, or the husband's educational level. The study recommended providing psychological and educational counseling services for married students in the age group of 31-40 years and create community awareness about the difficulties faced by married students and provide facilities and support for them and amending university study instructions to help contain the special situation of married students.
\end{abstract}

Keywords: married female students, bachelor's degree, world Islamic science \& Education University

\section{Introduction}

The education is a fundamental process in human life, the procedures of learning and acquiring knowledge has evolved with the development of societies and the expansion of the base of human civilization, the learning process has become an organized system provided by specialized corporation such as schools, institutes, and universities, also It includes all segments of society, including women, education with various dimensions has led to the development of societies and the advancement of humanity.

Higher education contributes significantly to community development. It is associated with the personal, social, economic and cultural aspects of the human being, and provides the appropriate opportunities for people to enjoy a high quality of life, helps in understanding societal norms; gives individuals self-confidence, and takes into account non-discrimination based on sex, religion, and social class, and for women higher education contributes to improve their social and life status generally. Higher education also enables women to become leaders in society, allows them to become role models for young girls, and contributes to their qualification to become decision-makers and influences on political, social, economic and cultural developmental issues. Educated women have a greater sense of control over their lives and more power, and control over resources within the family compared to uneducated women, they get social recognition and educated females can generally be better. University education is empowering women by helping them to become leaders in society and allowing them to become role models for young girls, educated women have greater ability to manage their lives and more power and control over resources within the family than uneducated women with social acceptance, also educated females can achieve better status at all levels (Shaukat\& William Pell,2015).

Yasmin, Saeed \& Ahmad (2018) indicated that students get exposure to life in different ways at the personal, academic and administrative level and they face many challenges like administrative, academic and financial. The mission statements of almost all the higher educational institutions claim that universities and colleges seek 
to provide excellent teaching and a high-quality learning environment. However, the rules are not implemented due to certain barriers at various levels especially, administrative, academic and financial.

Over the past 50 years, the pace of change in higher education has accelerated so that women are now more than 50 percent of university students in most countries. The issue of gender equality in universities and the contribution of women's studies is an important topic. It is noticeable that gender equality has been achieved through a balance between male and female students, whether it is in the bachelor's degree or postgraduate studies and courses. UNESCO launched an Atlas published in 2012, which is a clear example of the international commitment to gender equality around the world, including all levels of education. This atlas provides a vast amount of statistical information about the whereabouts of men and women as students all over the world and linking the information to international standards. It is quite clear from the publication of the World Atlas that education is a vital component of today's economies and that the goal of education for all is a reality ( David,2015).

Undergraduate is a time of self-discovery, exploration of the world, society and independence in general, but what happens when university students are married? In the case of marriage, each spouse often waives some of his interests for the benefit of the relationship and partner, and this affects the level of personal independence, and students usually face many pressures, these include continuous assessment, pressure to earn good grades, time pressures, unclear tasks, heavy workload, uncomfortable classrooms, and relationships with family and friends (Lasode \& Awotedua, 2014).

Married student suffers from many difficulties, most notably the pressure related to homework, married student with children often wakes up very early in the morning trying to get everything done at home before going to lectures and becomes tired and inconsistent with university lectures, married female students also suffer from fatigue, stress and lack of time to do homework, comfort and feelings of guilt to not meet the expectations of the traditional role in the home, on campus, it is often noticed that there is a lack of support for mothers, and this makes childcare a problem and academic programs ignore the need of women during pregnancy, childbirth and maternity leave, if ignoring this creates an atmosphere of distress and then the students of mothers feel that their problem has not been taken care (Amos\& Manieson, 2015)

Learning as a life mission needs concerted societal efforts to facilitate enrollment and fulfill its tasks, and concerning Jordanian society, the prevailing societal culture in it encourages education and higher education, this is confirmed by the existence of ten public universities and eighteen private universities in a country of ten million people, this helps in researching any issue or topic related to developing or improving education and its outputs, since the sample of the study from the Jordanian society in which the Islamic religion prevails, which recommended charity for women, the research stages the topic of the reality of married women have received support and encouragement at all levels.

\section{Study Problem}

Through my academic work as a faculty member at the university, I met many married students who expressed difficulties and challenges that they face such as accumulating domestic workloads with homework, in addition to the lack of laws and legislation supporting them within the university system, from here came the idea of research, knowing that the common culture in Jordan encourages education, encourages marriage, and family formation and parenting, also, this culture encourages education and surrounds it with an advanced societal view, as a result of the increasing number of married female students in universities, it has become necessary to know the reality of these students in university education based on the prevailing social context, these students may have difficulties with multiple roles without paying attention to them, family pressures may result from difficulties, these students may suffer from marital difficulties and the possibility of inadequate childcare.

\section{The Importance of Studying}

Theoretical significance: The present study provided a scale to measure the difficulties that married students may face, this study also provides a theoretical material that sheds light on the reality of married students in the World Islamic Science \& Education University and can be used for similar study samples in other studies communities.

Applied importance: the study may shed light on the mechanism of collecting data on the reality of married students and analyzing them and progress appropriate recommendations that contribute to improving the reality of married students who are in the university seats. 


\section{Purpose of the Study}

The study aims to collect data that contribute to the identification of the reality of married students by answering the following study questions:

1. What is the level of difficulties faced by married students in the World Islamic Science \& Education University?

2. Are there any statistically significant differences at the level $(\alpha \geq 0.05)$ in the level of difficulties faced by married students in the World Islamic Science \& Education University due to the age variable?

3. Are there any statistically significant differences at the level $(\alpha \geq 0.05)$ in the level of difficulties faced by married students in the World Islamic Science \& Education University due to the variable number of children?

4. Are there any statistically significant differences at the level $(\alpha \geq 0.05)$ in the level of difficulties faced by married students in the World Islamic Science \& Education University due to the variable income of the family?

5. Are there any statistically significant differences at the level of $(\alpha \geq 0.05)$ in the level of difficulties faced by married students in the World Islamic Science \& Education University due to the variable level of education the husband?

\section{Literature}

Upon reviewing the theoretical literature, it was concluded that married students face a special case, and therefore some cases were reviewed in studies and researches that mention them.

Akpotor (2018) conducted a study aimed at identifying the impact of life roles on the academic performance of married students, the study was conducted at Delta State University/ Abraka, the study was conducted on (280) married students and (120) single students. The data was collected by a questionnaire prepared for this study, and the results showed that the conflict of roles has a significant impact on academic performance, based on the results, it was recommended to contribute to capacity development to deal effectively with conflicting roles.

The study by Abu Hassuneh (2017) aimed to explore the level of psychological stress and mental health and the relationship between them among married students at Irbid National University based on the variables: school year, Cumulative average, and having children or not. It also aimed to identify the most common sources of stress among study participants. The sample of the study consisted of (120) married students at the National University of Irbid/Jordan, the researcher used two measures: a measure of psychological pressure developed by the researcher, and a scale of mental health that was developed by (Shraeefeen,2014). The results of the study showed that the level of psychological pressure is high and that the level of mental health was low, and that there is a negative correlation between psychological stress and mental health among married students, and the results have shown that there are differences in levels of psychological stress on the following variables: the year of the study, cumulative average and the presence of children in favor of the year first, the results showed that there were differences in mental health levels on the following variables: the school year, and having children in favor of the fourth year.

Behold and colleges (2016) finished the study purpose to explore the social, cultural, financial and academic problems of married students, the sample of the study included 20 female students enrolled in Rawalpindi and Islamabad private universities. The research methodology was based on a descriptive research methodology and a qualitative approach to collecting data with semi-regular interviews. Through research and conclusion procedures was concluded that some families in Pakistan do not allow university enrollment for females in general and married women in particular due to some social, cultural and religious factors. In addition to economic factors, the study also showed that providing access to education for married women depends on the support of the family and husband, knowing that some conservative families have approved the process of enrollment in the university to study the threat of moral level, and the difficulty of access from places to universities, the study recommended that the higher education system facilitate the admission of married women to the university without contradicting their roles as mothers, wives, and housewives.

Mbagwu, Nwobi, Ngozi, Ugwuoke, Igwe \& Ngozi (2016) finishing study which explained challenges facing married students at the University in Enugu State, Nigeria in the Southeastern Education District, which includes the following regions: Ago, Enugu, Apollo Asfour, Agbani and Odi Ann Asoka. The study adopted the design of descriptive investigative research, the questionnaire consisted of 26 paragraphs, developed on a 4-point assessment scale, was used to obtain information on study data. Intentional sampling was used. 387 married 
women were selected from a group of students at the University of Nigeria's College of Education. Married students between the ages of 20 and above. Lowering academic performance, destabilizing marital relationship with no financial support from the husband and the surrounding community, and based on the results, the researchers suggested the need to continue the path of married women.

Study by Amos \& Manieson (2015) purpose of identifying local and academic challenges that married women face in higher education institutions. A qualitative approach has been 30 women married to university students were selected, difficulty was observed in caring for their family's while being asked to perform academic assignments the main causes of the challenges were identified, including financial challenges and the performance of marital responsibilities at home. Women in the study sample indicated a low concentration during lectures and a decrease in academic performance in general. The study recommended the importance of reducing the pressure from family members and providing support and facilities from higher education institutions.

This study by Amos \& Manson ( 2015 ) aimed to identify local and academic challenges facing married women in higher education institutions, and a qualitative approach was adopted for this purpose, a purposive sample of 30 married students was used ,It was observed that they had difficulty in caring for their families due to the accumulation of homework, and the academic assignments that were to be accomplished within a short period, these challenges were financial constraints and the performance of marital responsibilities at home. The students expressed that these challenges led to low concentration during the lectures and lead to low academic performance. The study recommended the role of the family in reducing the pressure on married students and reducing the number of programs that had to be covered at the university could help them deal with overlapping roles.

Olukemi Lasode and Awotedu (2013) conducted a targeted study to know the different challenges facing married female university students in universities in Ogun State, Nigeria, the factors responsible for the challenges, difficulties, and implications. The study used the survey design with a sample of 150 married university students who were deliberately selected from two of the six universities in Ogun State. The combination of working with family responsibilities and university obligations has resulted in psychological stress in 108 of the total and $83.1 \%$ of female respondents, and this has had the greatest impact on their public lives.

Through reviewing the previous studies, we find that the issue of married female students is an important across many cultures, and some researchers have examined it because it's very important. Some studies dealt with the distress facing married women, and some dealt with academic or family pressures, note that the current study worked to get to know the reality of married students without referring directly to problems or pressures.

\section{Methodology}

The current study relied on the descriptive approach, where it aimed to identify the reality of married students at the university by identifying the difficulties they face.

\subsection{Study Population}

The study population consisted of female students registered in the second semester of the academic year 2018 /2019 in the World Islamic Science \& Education University /Amman- Jordan as they reached 75 female students.

\subsection{Study Sample}

The study sample was chosen by announcing it and its goals among university students and providing an opportunity to participate in the study for all married students, and accordingly, the number of volunteer students to participate in the study was 64 students.

\subsection{Study Questions}

The study aimed to identify the reality of married students in the World Islamic Science \& Education University /Amman - Jordan, and that is by answering the study questions:

1 .What is the level of difficulties faced by female married students at the World Islamic Science \& Education University?

2- Are there any statistically significant differences at the level $(\alpha=0.05)$ of difficulties faced by female married students in the World Islamic Science \& Education University due to the age variable?

3 -Are there any statistically significant differences at the level $(\alpha=0.05)$ of difficulties faced by female married students in World Islamic Science \& Education University due to the variable number of children? 
4 -Are there any statistically significant differences at the level $(\alpha=0.05)$ of the difficulties faced by female married students in the World Islamic Science \& Education University due to the family income variable?

5 - Are there any statistically significant differences at the level $(\alpha=0.05)$ of difficulties faced by female married students in the World Islamic Science \& Education University due to the variable level of education?

\subsection{Tool}

To achieve the objectives of the study, the researcher prepared a scale consisted of 20 paragraphs, every five paragraphs are a dimension: academic, social, psychological, and economic dimension.( Appendix no. 1)

The scale was designed by conducting the first survey to find out the status of married students and some of the difficulties they may face.

The scale included Quadruple Likert rating,1 Very Low degree, 2 Low degree,3 Medium degree, and 4 High degrees.

\subsection{Validity and Stability of the Scale}

To ascertain the characteristics and validity difficulties scale which measures the difficulties faced female married students in the World Islamic Science \& Education University, the researcher calculated the stability of the coefficient " Cronbach Alpha " and calculated the validity of the scale in a way that internal consistency calculation Pearson correlation coefficient of the scale with the scale as a whole.

\subsection{Stability}

the Cronbach Alpha coefficient is 80 . this indicates that the scale of difficulties faced by female married students in the International Islamic University of Science has a good degree of stability.

\subsection{Validity}

Table 1. Vocabulary Correlation Coefficients of Scale with Scale as a whole:

\begin{tabular}{cccc}
\hline $\begin{array}{c}\text { Paragraph } \\
\begin{array}{c}\text { Paragraph correlation } \\
\text { coefficient with the } \\
\text { scale as a whole }\end{array}\end{array}$ & $\begin{array}{c}\text { Paragraph } \\
.606^{* *}\end{array}$ & $\begin{array}{c}\text { Paragraph correlation } \\
\text { coefficient with the } \\
\text { scale as a whole }\end{array}$ \\
\hline 1 & $.325^{* *}$ & 11 & $.250^{*}$ \\
2 & $.429^{* *}$ & 12 & $.424^{* *}$ \\
3 & $.262^{*}$ & 13 & $.584^{* *}$ \\
4 & $.476^{* *}$ & 14 & $.556^{* *}$ \\
5 & .205 & 15 & $.555^{* *}$ \\
6 & $.453^{* *}$ & 16 & $.463^{* *}$ \\
7 & $.544^{* *}$ & 17 & $.374^{* *}$ \\
8 & $.485^{* *}$ & 18 & $.456^{* *}$ \\
9 & $.679^{* *}$ & 19 & $.548^{* *}$ \\
10 & 20 & $.545^{* *}$ \\
\hline
\end{tabular}

\footnotetext{
$* *$ Significance level $(\alpha \leq 0.01) *$ Significance level $(\alpha \leq 0.05)$
}

Table (1) show that all correlation coefficients between the paragraphs of the scale and the degree of the scale as a whole are greater than .19 which is statistically significant at $\alpha \leq 0.05$ and $\alpha \leq 0.01$, which is evidence of the consistency of the internal structure of the public health scale.

\subsection{Scale Correction Key}

Calculate the integer considering that the Likert scale used in the study according to the rules and characteristics of the scales as follows:

The values of the averages reached by the study were dealt between high value and the minimum value of the answer: alternatives divided by the number of levels:

$\frac{1-4}{3}=\frac{-3}{3}=-1$ This value is equal to the length of the class.

Thus, the low level of $1.00 \_1.99$ 
The medium level is 2.00_2.99

The high level is 3.00 and 4.00

\subsection{Study Sample}

Table (2) shows data of the study sample: -

Table 2. Distribution of Study Sample Variables

\begin{tabular}{|c|c|c|c|}
\hline variable & \multicolumn{3}{|c|}{$\begin{array}{l}\text { The } \\
\text { number }\end{array}$} \\
\hline \multirow[t]{3}{*}{ Student work } & Work & 13 & $20.3 \%$ \\
\hline & Not Work & 51 & $79.7 \%$ \\
\hline & Total & 64 & $100 \%$ \\
\hline \multirow[t]{4}{*}{ Age } & Less than 30 years & 22 & $34.4 \%$ \\
\hline & 31-40years & 22 & $34.4 \%$ \\
\hline & 41years and above & 20 & $31.3 \%$ \\
\hline & Total & 64 & $100 \%$ \\
\hline \multirow[t]{5}{*}{ Academic year } & First-year & 9 & $14.1 \%$ \\
\hline & Second Year & 25 & $39.1 \%$ \\
\hline & Third-year & 16 & $25.0 \%$ \\
\hline & Fourth-year & 14 & $21.9 \%$ \\
\hline & Total & 64 & $100 \%$ \\
\hline \multirow[t]{3}{*}{ Number of children } & 2 and below & 25 & $39.1 \%$ \\
\hline & 3 and above & 39 & $60.9 \%$ \\
\hline & Total & 64 & $100 \%$ \\
\hline \multirow{3}{*}{$\begin{array}{c}\text { The educational level of the } \\
\text { husband }\end{array}$} & Diploma and less & 34 & $53.1 \%$ \\
\hline & Bachelor's and above & 30 & 46.95 \\
\hline & Total & 64 & $100 \%$ \\
\hline \multirow[t]{3}{*}{ Family income } & Less than $600 \mathrm{JD}$ & 25 & $39.1 \%$ \\
\hline & More than $600 \mathrm{JD}$ & 39 & $60.9 \%$ \\
\hline & Total & 64 & $100 \%$ \\
\hline
\end{tabular}

\section{Results}

This study aims to recognitions the reality of female married students at the World Islamic Science \& Education University by answering the following questions:

First question: What are the difficulties faced by female married students in the World Islamic Science \& Education University?

To answer this question, has been calculated the averages and standard deviations of the difficulties level facing female married students at the World Islamic Science \& Education University, It is clear from the results that the overall average measure of the difficulties faced female married students in the World Islamic Science \& Education University, was medium and a mean of (2.07) and a standard deviation of (.454) while the averages of paragraphs ranged between (1.23 and 2.70) where the paragraph Which says "I feel pressure due to the accumulation of homework"

As the paragraph states, "I feel pressure as a result of accumulating homework" ranked first with an average of (2.70) and a standard deviation of (954), and the last paragraph is I have a lack of clarity of my study goals with an average of (1.23) and a standard deviation of (527.) 
Second question: Are there any statistically significant differences at $(\alpha=0.05)$ in the level of difficulties faced by female married students in World Islamic Science \& Education University, due to the age variable?

To answer this question, the arithmetic averages and standard deviations of the study sample scores were calculated on the scale of difficulties faced by female married students in the World Islamic Science \& Education University, one-way ANOVA analysis was used, and the results are presented below.

Table 3. averages and standard deviations of the study sample scores on the scale of the difficulties faced by female married students according to the age variable

\begin{tabular}{ccccc}
\hline Variable & Category & $\begin{array}{c}\text { The } \\
\text { number }\end{array}$ & Averages & Standard Deviation \\
\hline Age & $18-30$ years & 22 & 2.21 & .404 \\
& & & .472 \\
& $31-40$ years & 22 & 2.13 & .420 \\
& 41 years and up & 20 & 1.84 & .454 \\
& Total & 64 & 2.07 & \\
\hline
\end{tabular}

The results appear in the table (3) indicate the existence of apparent differences between the arithmetic averages of the study sample scores on the scale of the difficulties faced female married students in the World Islamic Science \& Education University, according to age variable, and to know the significance of differences were applied one- way ANOVA analysis.

Table 4. Results of One - Way ANOVA Analysis Test to Find Difference on Difficulties Scale for Married Female Students by Age Variable

\begin{tabular}{cccccc}
\hline variance & $\begin{array}{c}\text { Total } \\
\text { squares }\end{array}$ & $\begin{array}{c}\text { Degrees } \\
\text { of } \\
\text { freedom }\end{array}$ & $\begin{array}{c}\text { Average } \\
\text { squares }\end{array}$ & $\begin{array}{c}\text { Value } \\
(F)\end{array}$ & $\begin{array}{c}\text { Statistical } \\
\text { significance }\end{array}$ \\
\hline $\begin{array}{c}\text { Between } \\
\text { groups }\end{array}$ & 1.555 & 2 & .777 & 4.139 & $.021^{*}$ \\
$\begin{array}{c}\text { Within } \\
\text { groups }\end{array}$ & 11.455 & 61 & .188 & & \\
Total & 13.009 & 63 & & & \\
\hline
\end{tabular}

\footnotetext{
* Significance level $(\alpha \leq 0.05)$
}

It is clear from the table (4) that there are statistically significant differences in the difficulties faced female married students in the World Islamic Science \& Education University according to age variable where the value of (F) calculated (4.139) at the level of significance (.021), to find out the source of the differences, a Chevy test was conducted for the post comparisons, and a table (7) showing these results.

Table 5. The results of the selection of Chevy for post-comparisons

\begin{tabular}{ccc}
\hline $\begin{array}{c}\text { Difficulties depending } \\
\text { on age }\end{array}$ & Difference in averages & Statistical significance \\
\hline 18-30 years & .08182 & .822 \\
From 31-40 years & .36909 & $.028^{*}$ \\
41 or more & .28727 & .109 \\
\hline
\end{tabular}

\section{*Significance level $(\alpha \leq 0.05)$}

The table (5) shows indicates statistically significant differences for the age group 31-40, there were no statistically significant differences for other age groups.

Third question: Are there any statistically significant differences in the level of difficulties faced by female married students in World Islamic Science \& Education University due to the variable number of children?

To answer this question, arithmetic averages and Standard deviations were calculated to measure the difficulties faced female married students in the World Islamic Science \& Education University according to the variable number of children, and a t-test of independent samples was used to determine the significance of differences, table (6) shown that. 
Table 6. Averages, Standard deviations, and T-test of independent samples to measure the difficulties faced female married students to the variable number of children.

\begin{tabular}{cccccccc}
\hline Scale & $\begin{array}{c}\text { number } \\
\text { of } \\
\text { children }\end{array}$ & $\begin{array}{c}\text { The } \\
\text { number }\end{array}$ & Averages & $\begin{array}{c}\text { Standard } \\
\text { deviation }\end{array}$ & $\begin{array}{c}T \\
\text { value }\end{array}$ & $\begin{array}{c}\text { Degrees } \\
\text { of } \\
\text { freedom }\end{array}$ & $\begin{array}{c}\text { Statistical } \\
\text { significance }\end{array}$ \\
\hline Difficulties & $\begin{array}{c}2 \text { and } \\
\text { below } \\
\text { 3and }\end{array}$ & 25 & 2.19 & .414 & 1.80 & 62 & .085 \\
& 39 & 1.99 & .467 & & & \\
\hline
\end{tabular}

\section{* Significance level $(\alpha \leq 0.05)$}

The table (6) shows that there are no statistically significant differences in the scale of the difficulties faced female married students in the World Islamic Science \& Education University according to the variable number of children, where the value of (T) 1.800 and this value is not significant at the level of $(\alpha=0.085)$.

Fourth question: Are there any statistically significant differences at $(\alpha=0.05)$ in the level of difficulties faced by female married students in the World Islamic Science \& Education University due to the family income variable?

To answer this question, arithmetic averages and deviations were calculated to measure the difficulties faced by female married students at the World Islamic Science \& Education University according to the family income variable, and t-test for independent samples was used to determine the significance of differences as shown in table (7).

Table 7. Arithmetic averages, standard deviations and T-test of independent samples to measure the difficulties faced by married students according to the family income variable.

\begin{tabular}{cccccccc}
\hline Scale & $\begin{array}{c}\text { Family } \\
\text { income }\end{array}$ & Number & Averages & $\begin{array}{c}\text { Standard } \\
\text { deviation }\end{array}$ & $\begin{array}{c}T \\
\text { value }\end{array}$ & $\begin{array}{c}\text { Degrees } \\
\text { of } \\
\text { freedom }\end{array}$ & $\begin{array}{c}\text { Statistical } \\
\text { significance }\end{array}$ \\
\hline Difficulties & $\begin{array}{c}\text { Less } \\
\text { than } \\
600\end{array}$ & 25 & 2.1080 & .44760 & .594 & 62 & .555 \\
& $\begin{array}{c}\text { More } \\
\text { than } \\
600\end{array}$ & 39 & 2.0385 & .46247 & & & \\
& & & & & & \\
& & & & & & \\
\hline
\end{tabular}

\section{* Significance level $(\alpha \leq \mathbf{0 . 0 5})$}

There are no statistically significant differences in the scale of the difficulties faced by married students at the World Islamic Science \& Education University according to the family income variable, where the value of (T).594

Fifth question: Are there significant differences at the level of significance $(\alpha=0.05)$ in the level of difficulties faced by female married students at World Islamic Science \& Education University due to the variable educational level of husband?

To answer this question, arithmetic averages and deviations were calculated to measure the difficulties faced by female married students at the World Islamic Science \& Education University according to the husband's educational level variable, table (8) shown that. 
Table 8. Arithmetic averages, standard deviations, and T-test of independent samples to measure the difficulties faced by female married students according to the variable of the educational level of husband.

\begin{tabular}{cccccccc}
\hline Scale & $\begin{array}{c}\text { The variable } \\
\text { educational } \\
\text { level of the } \\
\text { husband }\end{array}$ & Number & Averages & $\begin{array}{c}\text { Standard } \\
\text { deviation }\end{array}$ & $\begin{array}{c}T \\
\text { value }\end{array}$ & $\begin{array}{c}\text { Degrees } \\
\text { of } \\
\text { freedom }\end{array}$ & $\begin{array}{c}\text { Statistical } \\
\text { significance }\end{array}$ \\
\hline Difficulties & $\begin{array}{c}\text { Less than a } \\
\text { Diploma } \\
\text { Bachelor's } \\
\text { degree } \\
\text { and more }\end{array}$ & 34 & 2.2015 & .44047 & 2.667 & 62 & .010 \\
& & 1.9117 & .42623 & & & \\
\hline
\end{tabular}

\section{* Significance level $(\alpha \leq 0.05)$}

Table (8) shows There are apparent differences in the difficulties faced by married female students in the World Islamic Science \& Education University according to the variable educational level of husband. But the value of (T) 2.667 and this value is not significant at the level of significance $(\alpha \leq 0.05)$, the arithmetic averages for the category (Diploma and less) were higher than the arithmetic average for the category (Bachelor and above).

\section{Discussion}

The idea of the study came from the importance of identifying the reality of married students in the World Islamic Science \& Education University, this is due to the increase in the number of married female students registered at the university, the enrollment of married women to study at the university differs from what is customary for university students at the undergraduate level, as a result of the complexity of the life roles of married women, so the idea of this study was to get know the reality of those married students, therefore, married female students were enrolled in the various colleges of the university for the second semester of the academic year 2019/2020, the number of these students is 64, the scale of difficulties faced female students has been applied to the study sample, the results of the study showed the following:

Regarding the answer first question: What are the difficulties faced by female married students in the World Islamic Science \& Education University?

The result shows that the level of difficulties faced by married students appeared to be medium, this reflects that the difficulties faced married student are under control and that the overlapping of their social roles, including their role as students, are coherent and effective, this may be because the decision to enroll in university studies is mature and pre-planned, especially since the Jordanian society culture encourages obtaining university degrees, and it appreciates the individuals who graduated from universities, one of the highest indicators of the difficulties faced female students was the pressure resulting from the accumulation of homework, this is a natural reflection of the overlapping of social roles, while the lowest paragraph was a difficulty for married students is lack of clarity of academic goals, this confirms that although the student is married, her academic goals are clear and mature.

This is in contrast to the findings of the Akpotor study (2018) whose results indicated the role struggle of married female students. and also differed with the findings of the study conducted by Mbagwn et al. (2016) which indicated a high level of challenges facing married students, such as low academic performance and suffering from difficulties in the marital relationship.

About the second question: Are there any statistically significant differences at $(\alpha \leq 0.05)$ in the level of difficulties faced by female married students in the World Islamic Science \& Education University due to the age variable?

The statistical analysis showed differences in the level of difficulties experienced by married students, according to the age group, and the most of the age group suffers from difficulties related to enrollment in the university, which was for the age group from 31-40 years, this is a logical result of the association of this stage with many tasks and life roles, because females in this age group may be the mother of children in schools and universities, and the continuous care and follow-up that needs, especially if they have children in adolescence stage, which is an important stage in which the mother needs special strategies to manage the relationship with them, also, women at this age may be overburdened with obligations and burdens to take care of her mother and father who may be old age. 
About the age group from 18-20 years, the difficulties experienced are less than the age group of 31-40 and this is because married students at this stage have not children and still in small ages and the requirements simple care, in addition to that, joining the university came soon after finishing high school and getting used to the academic tasks, about the age group 40 or more, female students at this stage may decide to attend university as a result of having accomplished many life tasks and want to improve the quality of life, at this stage, the children have reached the stage of maturity and independence from the mother, therefore, the level of difficulties experienced female students at this stage will be few. The current study was distinguished from previous studies in that it studied the age variable and its impact on the difficulties faced by married students. The present study was distinguished by the fact that the study touched on the age variable, and previous studies did not address this variable.

Upon reviewing the third question: Are there any statistically significant differences in the level of difficulties faced by female married students in the World Islamic Science \& Education University due to the variable number of children?

The results of the study indicate that there are no differences in the degree of difficulties according to the variable number of children, this result explains that women who decided to go to university realizing the reality of family members, if the number of children is small, the difficulties for the mother are simple and her tasks are easy if the number of children is large, the possibility of cooperation and assistance between them increases, and this also reduces the difficulties of the mother, thus, the difficulties are similar for the number of children. This result is not the same as what the Hassouna study has reached (2017), Where the presence of children puts psychological pressure on married students at the university.

And the fourth question: Are there any statistically significant differences at $(\alpha \leq 0.05)$ in the level of difficulties faced by female married students in the World Islamic Science \& Education University due to the family income variable?

The results indicated that the family income variable does not effect on the level of difficulties faced married students, the decision to join the university may be based on a financial budget for the family's situation since the fees of the World Islamic Science \& Education University are slightly higher than the fees for government universities, the amounts of money that will be paid to the university are known before registration in university. Therefore, family income is not one of the difficulties faced by married students. Through a quick review of previous studies, these studies did not address the family income variable and thus can be considered one of the advantages of the current study.

Fifth and final question: Are there significant differences at the level of $(\alpha \leq 0.05)$ in the level of difficulties faced by female married students in the World Islamic Science \& Education University due to the variable educational level of the husband?

The results of the statistical analysis showed that there were apparent differences, and not statistically significant, according to the variable of the husband's educational level, the differences were in diploma degree or less, this may be due to the low level of knowledge and awareness the nature of university study among couples at the diploma level or less, this may reflect some inappropriate responses or to wives who are enrolled university, in contrast, husbands who hold a first university degree or more are more responsive to college wives and constitute more support, the previous studies did not address the variable of the husband's educational level, and in this context, we find that the current study is distinguished by the study of this variable.

\section{Recommendation:}

Based on the findings of the study, I suggest the following recommendations:

-Providing psychological and educational counseling services for married students between the ages of 31-40 years

- Create community awareness about the difficulties faced with married students and provide facilities and support for them.

- Amending university study instructions to help contain the special situation of married students

- Shed light on the burdens faced by women between the ages of 31-40 years to provide support from the family and the university.

- Conducting a specialized study to identify the relationship between the husband's educational level and the difficulties faced with married students.

- Conducting studies on the reality of married students in other universities and larger research samples 
(Appendix no. 1)

\begin{tabular}{|c|c|c|c|c|c|}
\hline Number & Paragraph & $\begin{array}{l}\text { Very little } \\
\text { degree }\end{array}$ & Low degree & $\begin{array}{l}\text { Medium } \\
\text { degree }\end{array}$ & $\begin{array}{l}\text { Great } \\
\text { degree }\end{array}$ \\
\hline 1 & $\begin{array}{l}\text { I feel pressure due to the } \\
\text { accumulation of homework }\end{array}$ & & & & \\
\hline 2 & $\begin{array}{c}\text { I find it difficult to study as a result of } \\
\text { my interruption }\end{array}$ & & & & \\
\hline 3 & $\begin{array}{l}\text { I have difficulty choosing the course that } \\
\text { suits me }\end{array}$ & & & & \\
\hline 4 & $\begin{array}{c}\text { My academic achievement is less than } \\
\text { my ambition level }\end{array}$ & & & & \\
\hline 5 & $\begin{array}{l}\text { I cannot understand the requirements of } \\
\text { the subjects }\end{array}$ & & & & \\
\hline 6 & $\begin{array}{l}\text { I face the disapproval of those around } \\
\text { the decision to join the university }\end{array}$ & & & & \\
\hline 7 & $\begin{array}{l}\text { I suffer from the failure to perform } \\
\text { social duties }\end{array}$ & & & & \\
\hline 8 & $\begin{array}{l}\text { I can't match my studies with my } \\
\text { children }\end{array}$ & & & & \\
\hline 9 & $\begin{array}{l}\text { It is difficult to complete both homework } \\
\text { and study }\end{array}$ & & & & \\
\hline 10 & $\begin{array}{l}\text { I have some difficulties in the } \\
\text { relationship with my husband as a result } \\
\text { of going to university }\end{array}$ & & & & \\
\hline 11 & $\begin{array}{c}\text { I suffer from blurring my academic } \\
\text { goals }\end{array}$ & & & & \\
\hline 12 & $\begin{array}{c}\text { I am very afraid of the idea of academic } \\
\text { failure }\end{array}$ & & & & \\
\hline 13 & I cannot manage time & & & & \\
\hline 14 & $\begin{array}{l}\text { I suffer from conflict due to the } \\
\text { intertwined social roles }\end{array}$ & & & & \\
\hline 15 & I have anxiety from time to time & & & & \\
\hline 16 & $\begin{array}{l}\text { I suffer from the inability to pay } \\
\text { university tuition }\end{array}$ & & & & \\
\hline 17 & $\begin{array}{l}\text { I have an increased financial burden as a } \\
\text { result of university references }\end{array}$ & & & & \\
\hline 18 & $\begin{array}{l}\text { Transportation to and from the } \\
\text { university is financially expensive }\end{array}$ & & & & \\
\hline 19 & $\begin{array}{l}\text { Costs for university clothes are a } \\
\text { financial burden }\end{array}$ & & & & \\
\hline 20 & $\begin{array}{c}\text { Personal expenses at the university have } \\
\text { become an additional cost }\end{array}$ & & & & \\
\hline
\end{tabular}

\section{References}

Abu Hassuneh \& Nashaat Mahmood (2017). Psychological stress and its relation to psychological health among married female students in Irbid National University, - JO International Journal of Research in Education and Psychology. https://doi.org/10.12785/IJREP/050205. 
Akpotor, Julie (2018). Role Conflict of Married Female Students and Academic performance. International Journal of Research in Humanities and Social Studies, 5(5), 2018, 27-32. ISSN 2394-6288.

Amos, Patricia Mawusi \& Manieson Esther (2015). Issues and Challenges Confronting Married Women in Tertiary Stitutions. International Journal of Education, Learning and Development, 3(9), 19-27.

Behlol ,Malik Ghulam \& Iqra Irfan, Najeebullah (2016). Problems of Married women at Higher Education in Pakistan Academic, Social and Cultural Context, International Journal of African and Asian Studies, ISSN 2409- 6938 An sInternational Peer-reviewed Journal, 20.

David, Miriam E. (2015). Women and Gender Equality in Higher Education, Education sciences, ISSN 2227-7102, Educ. Sci, 2015(5), 10-25. https://doi.org/10.3390/educsci5010010.

Lasode, Abolanle Olukemi \& Awotedua, Feyisola (2014). Challenges faced by married university undergraduate female students in Ogun State, Nigeria, International Conference on Education and Educational Psychology, Procedia - Social and Behavioral Sciences, 112(2014), $102-113$. https://doi.org/10.1016/j.sbspro.2014.01.1144

Mbagwu, F. O., Nwobi, A. U., Ngozi Ugwuoke \& Igwe, Ngozi (2016). Challenges Facing Married Female Students in the University: Issues and The Way Forward. Transylvanian Review, XXIV(10)

Olukemi Lasodea, Abolanle \& Awotedu, Feyisola (2014). Challenges faced by married university undergraduate female students in Ogun State, Nigeria, Procedia - Social and Behavioral Sciences, 112(2014), $102-113$. https://doi.org/10.1016/j.sbspro.2014.01.1144

Shaukat, Sadia \& William Pell, Anthony (2015). Personal and Social Problems Faced by Women in Higher Education FWU. Journal of Social Sciences, Winter 2015, 9(2), 101-109.

Yasmin, Farhana, Saeed, Muhammad \& Ahmad, Naseer (2018). Challenges Faced by Postgraduate Students: A Case Study of a Private University in Pakistan. Journal of Education and Human Development, 7(1), 109-116. ISSN: 2334-296X (Print), 2334-2978 (Online).

\section{Copyrights}

Copyright for this article is retained by the author(s), with first publication rights granted to the journal.

This is an open-access article distributed under the terms and conditions of the Creative Commons Attribution license (http://creativecommons.org/licenses/by/3.0/). 